Jurnal Ekonomi Syariah Darussalam

Vol I No I Agustus 2020, ISSN: 2745-8407

\title{
TINJAUAN HUKUM ISLAM TERHADAP PRAKTIK JUAL BELI TANAH DI DESA KARANGDORO KECAMATAN TEGALSARI KABUPATEN BANYUWANGI
}

\author{
Muhammad Ala'uddin', Mukhtar Syafaat ${ }^{2}$ \\ Universitas Qomaruddin ${ }^{1}$, Institut Agama Islam Darussalam (IAIDA) Blokagung \\ Banyuwangi ${ }^{2}$ \\ Email: damascuter@gmail.com¹,Aatsyafaat911@gmail.com²
}

\begin{abstract}
This study aims to determine the practice and review of Islamic law related to the sale and purchase of land in Karangdoro Village, Tegalsari District, Banyuwangi Regency and to find out. The results obtained from research on the practice of buying and selling land in Karangdoro Village. In buying and selling through a broker, a broker gets 5\% of the proceeds from the sale, which percentage has become a local custom or taken from the additional selling price of the land. In addition, it is usually when a land owner asks for the net price of the land sale. After knowing the price asked by the land owner, the realtor will find a buyer and offer the goods. After the broker makes a price agreement with the buyer, the buyer will be brought together with the land owner to make an agreement or agreement. The sale and purchase transaction of land in Karangdoro Village is legal according to the review of Islamic law, because it is in accordance with the terms and conditions of sale and purchase, and the increase in prices made by brokers in selling land is permitted under Islamic law because it has received permission from the land owner.
\end{abstract}

\section{Keywords: Buying and Selling, Islamic Law}

\begin{abstract}
Abstrak
Penelitian ini bertujuan untuk mengetahui praktek dan tinjauan hukum Islam terkaitjual beli tanah di Desa Karangdoro Kecamatan Tegalsari Kabupaten Banyuwangi dan untuk mengetahui hasil yang diperoleh dari penelitian mengenai praktek jual beli tanah di Desa Karangdoro. Dalam jual beli melalui makelar, seorang makelar mendapatkan 5\% dari hasil penjualan yang mana persenan tersebut sudah menjadi adat setempat atau mengambil dari penambahan harga jual tanah. Dalam penambahan tersebut biasanya ketika seorang pemilik tanah meminta harga bersih dari penjualan tanah. Setelah mengetahui harga yang diminta oleh pemilik tanah, makelar akan mencari pembeli dan menawarkan barangnya. Setelah makelar melakukan kesepakatan harga dengan pembeli, maka pembeli akan di pertemukan dengan pemilik tanah untuk melakukan sebuah perjanjian atau kesepakatan. Transaksi jual beli tanah tanah di Desa Karangdoro sah menurut tinjauan hukum Islam, karena sudah sesuai dengan ketentuan syarat dan rukun jual beli, dan penambahan harga yang dilakukan makelar dalam menjual tanah di perbolehkan secara hukum Islam karena sudah mendapatkan izin dari pemilik tanah.
\end{abstract}

Kata Kunci: Jual Beli, Hukum Islam 
Jurnal Ekonomi Syariah Darussalam

Vol I No I Agustus 2020, ISSN: 2745-8407

\section{A. PENDAHULUAN}

Fiqh muamalah adalah salah satu ilmu pengetahuan yang membahas tentang hukum-hukum syariat yang praktis yang diambil dari-dalil yang berkaitan dengan segala perbuatan manusia. Salah satunya adalah menjelaskan tentang perpindahan hak milik barang dari seseorang ke orang lain, misalnya melalui jual beli atau $a l$ $b a$ ' $i$. Dalam jual beli terdapat pertukaran barang satu dengan barang yang lain, yang mengakibatkan terdapat pertukaran barang satu dengan barang yang lain, yang mengakibatkan perpindah hak milik barang dari seseorang ke orang lain atau dari penjual ke pembeli (Abdullah, Saebani, 2014:108)

Jual beli (bai') menurut bahasa adalah tukar menukar sesuatu. Sedangkan secara istilah jual beli (bai') adalah transaksi tukar menukar materi yang berisikan konsekoensi kepemilikan barang atau jasa secara permanen (mu'abbad) (Tim Laskar Pelangi, 2013:2). Dalil yang mendasari legislasi transaksi jual beli adalah ayat Al-Quran yang menerangkan tentang jual beli adalah;

وَأَحَلَّ اللَّهُ الْبَيْعَ وَحَرََّمَ الرِّبَا Artinya: "..Padahal Allah telah menghalalkan jual beli dan mengharamkan riba..." (Departemen Agama RI, 2012:83).

Salah satu desa di Kecamatan Tegalsari Kabupaten Banyuwangi yaitu Desa Karangdoro, ketika seseorang terdesak dengan kebutuhan mendadak, maka mereka akan menjual tanah atau benda yang layak untuk diperjual belikan. Dalam menawarkan barangnya, seorang penjual biasanya menawarkan dengan sendiri dan ada juga yang menggunakan jasa perantara yang ada di desa tersebut, yang mana perantara/makelar tersebut bisa mempermudah dalam menjual tanah/barang mereka. Contoh jual beli yang menggunakan jasa perantara/makelar yaitu jual beli tanah di desa.

Dalam praktik pemakelaran biasanya makelar hanya sebagai seorang perantara antara penjual dan pembeli yang mana makelar akan mendapatkan upah ketika sudah menyelesaikan pekerjaan tersebut. Akan tetapi Pemakelaran tanah yang terjadi di Desa Karangdoro terkadang dalam melakukan praktiknya banyak yang tidak sesuai dengan hukum Islam seperti menambah harga jual beli Tanah tanpa sepengetahuan pemilik dan pembeli tanah dan pemberian upah yang masih belum jelas nominalnya. 
Jurnal Ekonomi Syariah Darussalam

Vol I No I Agustus 2020, ISSN: 2745-8407

Berdasarkan praktik di atas dapat dilihat bahwa, penambahan harga yang dilakukan oleh makelar terkadang bisa merugikan dari kedua belah pihak, baik penjual maupun pembeli karena ketidak wajaran mereka dalam menambah harga jual tanah tersebut. Maka berdasarkan alasan itulah peneliti menganggap bahwa masalah tersebut perlu di kaji secara mendalam untuk mengetahui keabsahan dari praktek jual beli yang dilakukan. Berdasarkan latar belakang di atas, maka permasalahan yang diteliti adalah sebagai berikut: 1) Bagaimana praktek jual beli tanah di Desa Karangdoro Kecamatan Tegalsari Kabupaten Banyuwangi? 2) Bagaimana Tinjauan Hukum Islam terhadap praktek jual beli tanah di Desa Karangdoro Kecamatan Tegalsari Kabupaten Banyuwangi?.

\section{B. LANDASAN TEORI}

\section{Pengertian Fiqh Muamalah}

Kata fiqh secara etimologi adalah (الفقه) yang memiliki makna pengertian atau pemahaman (Munawir, 2008:1098). Menurut terminologi, fiqh pada mulanya berarti pengetahuan keagamaan yang mencakup seluruh ajaran agama, baik berupa aqidah, akhlak, maupun ibadah sama dengan arti syariah Islamiyah. Namun, pada perkembangan selanjutnya, fiqh diartikan sebagai bagian dari syariah Islamiyah, yaitu pengetahuan tentang hukum syariah Islamiyah yang berkaitan dengan perbuatan manusia yang telah dewasa dan berakal sehat yang diambil dari dalildalil yang terinci (Syafei, 2001:11).

Secara bahasa muamalah berasal dari kata amala yu'amilu yang artinya bertindak, saling berbuat, dan saling mengamalkan. Sedangkan menurut istilah muamalah adalah tukar menukar barang atau sesuatu yang memberi manfaat dengan cara yang ditentukan muamalah juga dapat diartikan sebagai segala aturan agama yang mengatur hubungan antara sesama manusia, dan antara manusia dan alam sekitarnya tanpa memandang perbedaan (Syafei, 2001:14).

\section{Pengertian Jual Beli}

Jual beli (bai') menurut bahasa adalah tukar menukar sesuatu. Sedangkan secara istilah jual beli (bai') adalah transaksi tukar menukar materi yang berisikan konsekoensi kepemilikan barang atau jasa secara permanen (mu'abbad) (Tim Laskar Pelangi, 2013:2). 
Jurnal Ekonomi Syariah Darussalam

Vol I No I Agustus 2020, ISSN: 2745-8407

Sedangkan definisi jual beli dalam kitab Fathul Qorib ialah memiliki suatu yang harta (uang) dengan mengganti sesuatu dengan atas ijin syara', atau sekedar memiliki manfaatya saja yang diperbolehkan syara'. Yang demikian itu harus dengan pembayaran yang berupa uang (fathul Qorib: 30:1999).

Istilah jual beli ( bai $^{\prime}$ ), pada hakikatnya bukan termasuk maliyyah. Kategori jasa atau manfaat sebagai maliyyah, hanya sebatas sebagai majaz, sebab eksistensinya bersifat abstrak (Ma'dumah) dan lebih di karenakan demi mentolelir keabsahan mengadakan transaksi jasa (Manfa'ah) (Tim Laskar Pelangi, 2013:2).

\section{Penelitian Terdahulu yang Relevan}

Penelitian yang berkaitan dengan jual beli memang telah banyak dibahas dalam skripsi yang telah lalu. Diantaranya "Tinjauan Hukum Islam terhadap Jual Beli Tanah Pemakaman Modern di Karawang” yang di tulis oleh Sulaiman Afandy. Mahasiswa Universitas Islam Negeri Sunan Kalijaga Yogyakarta, yang membahas tentang jual beli tanah pemakaman modern dengan kesimpulan jual beli yang dilakukan sudah memenuhi syarat dan rukun jual beli hanya saja dalam prakteknya kurang memenuhi prinsip-prinsip muamalah yaitu kesederhanaan dan kemaslahatan. Persamaan dengan penelitian ini adalah pembahasannya tentang jual beli tanah an juga sama-sama menggunakan metode deskriftif kualitatif, sedangkan perbedaannya terletak pada tempat penelitian dan terfokus pada penjualan tanah secara kavling saja (Sulaiman Afandy, 2015:2).

Skripsi berjudul "Tinjauan Hukum Islam Terhadap Jual Beli Tanah Sawahan di Desa Ngabar Kecamatan Siman kabupaten Ponorogo" yang di tulis oleh Ifda Faridatul Khiftyani mahasiswi IAIN Ponorogo, menekankan pada tinjauan hukum Islam terhadap jual beli tanah sawahan dengan kesimpulan bahwa akad jual beli ini sah menurut hukum adat istiadat setempat, tetapi menurut hukum Islam tidak sah. Baik penjual maupun pembeli harus bertemu langsung dalam satu majlis sehingga menemukan kesepakatan antara kedua belah pihak. Persamaan dengan penelitian ini adalah pembahasannya mengkaji tentang jual beli tanah dan juga sama-sama menggunakan metode deskriftif kualitatif, sedangkan perbedaannya terletak pada waktu dan tempat penelitian dan pembahannya lebih khusus jual beli (Ifda Faridatul Khiftyah, 2016:3). 
Jurnal Ekonomi Syariah Darussalam

Vol I No I Agustus 2020, ISSN: 2745-8407

C. METODE PENELITIAN

\section{Jenis Penilitian}

Jenis penelitian yang peneliti gunakan adalah penelitian deskriptif kualitatif, penelitian kualitatif adalah penelitian yang menggunakan data deskriptif berupa kata-kata tertulis atau lisan dari orang-orang dan perilaku yang diamati. Selain itu penelitian kualitatif merupakan penelitian yang menggunakan latar ilmiah, dengan maksud menafsirkan fenomena yang terjadi dan dilakukan dengan jalan melibatkan berbagai metode yang ada (Sugiono, 2004:1).

Penerapan pendekatan kualitatif dengan pertimbangan kemungkinan data yang diperoleh dilapangan berupa data dalam bentuk fakta yang perlu adanya analisis secara mendalam. Maka pendekatan kualitatif akan lebih mendorong pada pencapaian data yang bersifat lebih mendalam terutama dengan keterlibatan peneliti sendiri di lapangan.

\section{Lokasi dan Waktu Penelitian}

Lokasi penelitian adalah tempat dimana proses study yang digunakan untuk memperoleh pemecahan masalah penelitian berlangsung. Pemilihan suatu lokasi penelitian harus didasari dengan pertimbangan yang baik agar bisa berjalan sesuai dengan rencana yang telah dibuat. Untuk itu suatu lokasi penelitian dipertimbangkan melalui mungkin tidaknya untuk dimasuki dan dikaji lebih mendalam. Selain itu penting juga dipertimbangkan apakah lokasi penelitian tersebut memberi peluang yang menguntungkan bagi peneliti untuk dikaji lebih dalam atau tidak.

Dalam penelitian yang dilakukan penulis memilih lokasi di Desa Karangdoro Kecamatan Tegalsari Kabupaten Banyuwangi yang diharapkan tempat penelitian tersebut memudahkan dalam mencari data. Waktu penelitian yang dilakukan peneliti yaitu mulai Bulan Mei hingga Agustus 2019.

\section{Data dan Sumber Data}

Sumber yang di gunakan peneliti dalm penelitian terbagi menjadi dua macam: 1) Sumber Data Primer, data primer yang digunakan dalam penelitian ini diperoleh dari orang-orang yang menjadi informan melalui observasi, wawancara dan dokumentasi. Dalam hal ini, yang menjadi sumber data primer adalah informasi dari penjual, pembeli dan makelar yang melakukan jual beli tanah yang berada di 
Jurnal Ekonomi Syariah Darussalam

Vol I No I Agustus 2020, ISSN: 2745-8407

Desa Karangdoro Kecamatan Tegalsari Kabupaten Banyuwangi. Adapun data primer yang digunakan dalam penelitian ini adalah yang diperoleh dari orang-orang yang menjadi informan melalui observasi, wawancara. 2) Sumber Data Skunder, data sekunder merupakan data pendukung yang memiliki fungsi sebagai pendukung atau penguat data utama. Dalam penelitian ini data sekunder tersebut biasanya berupa dokumen. Adapun data sekunder yang digunakan dari data pendukung seperti buku, jurnal penelitian, skripsi, arsip desa dan yang dapat menjadi rujukan dalam penelitian ini.

\section{Prosedur Pengumpulan Data}

Prosedur pengumpulan data dalam penelitian melalui: 1) Observasi, dalam hal ini peneliti meneliti langsung di Desa Karangdoro Kecamatan Tegalsari Kabupaten Banyuwangi. Observasi ini bertujuan untuk mengetahui bagaimana kegiatan jual beli tanah yang dilakukan Masyarakat Desa Karangdoro. 2) Wawancara, dalam penelitian ini penulis menggunakan bentuk wawancara tak terstruktur, dalam peneliti ini untuk memperoleh data Praktik jual beli tanah peneliti melakukan wawancara dengan 7 informan yaitu 3 makelar, 2 pemilik tanah dan 2 pembeli. 3) Dokumentasi, dalam penalitian ini, data atau dokumen yang digunakan yaitu data pada penduduk Desa Karangdoro Kecamatan Tegalsari Kabupaten Banyuwangi yang diperoleh dari perangkat desa, meliputi gambaran umum desa, letak geografis, kondisi demografis, keadaan Sosial agama, dan keadaan Sosial pendidikan.

\section{Alat Analisa Data}

Dalam menganalisis data, tehnik analisis yang digunakan dalam penelitian ini adalah interaktif model, yang terdiri dari empat komponen yaitu pengumpulan data, mereduksi data, penyajian data, kesimpulan dan vertifikasi.

1. Pengumpulan Data, data yang muncul berwujud kata-kata, dilakukan dalam aneka cara yaitu wawancara mendalam. Kemudian data yang diperoleh diproses melalui tiga jalur kegiatan yaitu reduksi data, penyajian data dan perbaikan kesimpulan.

2. Reduksi Data (Data Reduction), Data reduction adalah kegiatan meringkas, memilah, memilih hal hal pokok dan memfokuskan pada hal hal yang penting dari data yang di peroleh di lapangan. Setelah di reduksi, data yang di tampilkan akan lebih jelas dan lebih mudah data yang di kumpulkan. 
Jurnal Ekonomi Syariah Darussalam

Vol I No I Agustus 2020, ISSN: 2745-8407

3. Paparan Data (Data Display), pemaparan data dalam penelitian ini merupakan sekumpulan informasi yang tersusun dan memberikan kemungkinan adanya penarikan kesimpulan dan pengambilan data.

4. Penarikan Kesimpulan / Verifikasi (Conclusion Drawing/Verifying), tahapan yang ke tiga yaitu penarikan kesimpulan dan verifikasi. Hasil kesimpulan di tampilkan dalam bentuk deskriptif objek penelitian berdasarkan pada hasil penelitian yang di lakukan.

\section{HASIL PENELITIAN DAN PEMBAHASAN}

\section{Verifikasi Data Lapangan}

Verifikasi adalah Penjelasan data dalam suatu konfigurasi yang secara jelas menunjukan kausulnya, sehingga dapat diajukan proposisi-proposisi yang terkait dengannya. Maka data tersebut dapat dimengerti dan penemuan yang dihasilkan dapat dikomunikasikan dengan orang lain atau bisa juga disebut dengan penyaringan data (Malinda, 2018:11). Pada pembahasan ini penulis akan memverifikasi data tentang jual beli di Desa Karangdoro Kecamatan Tegalsari Kecamatan Tegalsari.

Awal terjadinya praktek makelar Jual beli tanah di Desa Karangdoro Kecamatan Tegalsari Kabupaten Banyuwangi, makelar adalah seorang yang menjadi pelantara dalam jual beli yang mana dalam praktiknya terkadang berbeda antara satu dengan yang lain. Dari hasil Hasil wawancara dengan bapak Yamdadi praktik mekelar jual beli tanah sebagai berikut:

"Praktek pemakelaran tanah seng tak lakoni selama iki, biasane seng due tanah utowo seng golek tanah moro neng omah lan ngomongne maksud tujuane njalok tolong kon ngedolne tanae de'e utowo ngolekne tanah, mari nnono tak tekoi de'e njalok didol piro tanahe seumpomone dee njalok 100 juta utowo ngolek tanah seng koyok piye,regane piro mari ngono aku ngolek pembeli lan nawar ne tanah kuwi”.

Artinya: Praktik pemakelaran tanah yang saya lakukan selama ini, biasanya yang mempunyai tanah atau yang mencari tanah datang ke rumah untuk meminta dijualkan tanahnya atau dicarikan tanah. Sehabis itu saya tanya "minta berapa tanahnya" atau "cari tanah yang seperti apa, harga berapa" sehabis itu saya carikan pembeli dan menawarkannya."

Hal senada dikatakan oleh Bapak Soponyono beliau mengatakan:

"Prakteke kang. kwi wong seng duwe tanah moron de' aq tros nawakne tanahe utowo pembeli moron de' aku njalok digolekne tanah. Neng kono yo nentokne rogo 
Jurnal Ekonomi Syariah Darussalam

Vol I No I Agustus 2020, ISSN: 2745-8407

seng di jalok juga, trus perjanjian omongan karo aku, trus tak golekne wong seng ape tuku utowo tanah seng ape didol."

Artinya: "Praktiknya kang, itu orang yang mempunyai tanah datang ke saya menawarkan tanahnya atau pembeli minta dicarikan tanah. Disana nanti juga menentukan harga yang diminta, sehabis itu perjanjian sama saya".

Proses pelaksanaan pemakelaran jual beli tanah di Desa Karangdoro dari hasil wawancara dengan bapak Kundari pelaksanaan pemakelar jual beli tanah yang ada di Desa Karangdoro sebagai Berikut:

"Sakwise sen duwe tanah Konngedolne tanahe lan nentokne regane, maringono tak tawarne neng wong seng ape tuku. Coro seng duwe tanah njalok $100 \mathrm{jt}$ biasane aq bukak rego 130 jt kwi mau gak langsung dill tapi yo dinyang sampek sepakat regone. Ketika neng kono mari tak tawarke kok entok tambahan rego, yo tak omongne neng seng duwe tanah ben gak dadi balak kang. Lek ketika wong seng tuku wes sepakat karo rego seng tak taware, engko wonge tak temokne karo seng duwe tanah. La neng kono nko melakukan perjanjian biasane gae surat seng surate tego deso. Nko yo nekokne saksi. Saksine biasane pak RT, utowo ketua RW utowo kamituo, utowo wong seng duweni pengaruh karo wong seng diwehi tanah neng sekitar tanah seng di dol"

Artinya: "Sesudah orang yang mempunyai tanah menentukan harganya, lalu saya tawarkan kepada yang akan membeli tanah, seumpama pemilik tanah minta 100 juta biasanya saya tawarkan 130 juta, itu tadi tidak langsung deal tapi masih di tawar sampai kesepakatan harga. Kalau disitu sesudah saya tawaran ada kelebihan harga, maka saya aan beritahu yang mempunyai tanah tentang kelebihan itu. Ketika orang yang membeli sudah sepakat dengan harga yang saya tawarkan, nanti saya pertemukan dengan pemilik tanah. Nantinya ada surat perjanjian, yang mana surat tersebut dari desa, di situ juga ada saksi, biasanya saksinya bapak RT, Ketua RT, Kepala Dusun atau orang yang mempunyai pengaruh dan juga orang yang mempunyai tanah di sekitar tanah yang dijual".

Hal ini sesuai dengan yang dikatakan oleh Bapak Yamdadi:

"Prosese pemakelaran iku yo sakwise seng duwe tanah nentokne rego, maringono aku nggolekne pembeli. Neng kono tawar tawaran. Sakwise terjadi kesepakatan rego kok enek tambahan rego neng kono, yo tak omongne neng seng duwe tanah. Maringono tak temokne antara seng duwe tanah karo pembeline kanggo ngelakoni perjanjian."

Artinya: "Proses pemakelaran itu sehabis yang mempunyai tanah menentukan harga, lalu saya akan mencarikan seorang pembeli. Disitulah terjadi proses tawar menawar. Sehabis terjadi kesepakatan harga kalau ada tambahan harga, ya saya beritahu orang yang mempunyai tanah. Sehabis itu saya akan pertemukan antara pemilik tanah dan pembeli untuk melakukan perjanjian".

Selesainya pekerjaan makelar, hasil wawancara dengan bapak Yamdadi selesainya pekerjaan makelar di Desa Karangdoro Sebagai berikut: 
Jurnal Ekonomi Syariah Darussalam

Vol I No I Agustus 2020, ISSN: 2745-8407

"Lek wes mari ngelakoni perjanjian pekerjaan makelar mari. Maringono oleh upah songko seng duwe tanah. Biasane upae 5\% utowo njikok teko kelebihane iku mau."

Artinya: "Kalau sudah selesai melakukan perjanjian antara penjual dan pembeli pekerjaan selesai. Sehabis itu makelar mendapatkan upah dari yang mempunyai tanh, basanya 5\% atau mengambil dari kelebihan harga jual tanah".

Syarat makelar jual beli tanah di desa karangdoro, hasil wawancara dengan bapak Kholil syarat jual beli tanah di Desa Karangdoro sebagai berikut:

"Makelar kuwi adol tanah lekwes enek kongkonan teko seng duwe tanah. Lek enek penambahan harga teko seng di tentokne karo seng dwe tanah yo di omongne. Biasane makelar kwi entok upae lek wes mari pekerjaane karo ora onok ketentuan waktu teko nawakne mau."

Artinya: "Makelar itu menjual tanah kalau sudah disuruh oleh pemilik tanah. Kalau penambahan Harga dari apa yang sudah ditentukan ya di beritahukan kepada pemilik tanah. Biasanya makelar itu mendapatkan upah kalau sudah selesai pekerjaannya, sama tidak ada ketentuan waktu dari menawarkan harga tersebut".

Begitu juga yang dikatakan bapak Yamdadi

"Yo syarate gak enekmas, tapi nengkono makelar ngelakoni adol tanah lekwes enek ijin teko seng dwe tanah, karo upae kuwi mau lek wes mari pekerjaan lan ora dibatesi waktu ngedole tanah."

Artinya: "tidak ada syarat, tapi makelar melakukan jual beli tanah kalau sudah mendapatkan izin dari pemilik tanah, sama upahnya itu kalau sudah selesai pekerjaannya dan tidak ada batasan waktu."

Rukun jual beli tanah di Desa Karangdoro, hasil wawancara dengan bapak Katimin menyebutkan bahwasanya rukun jual beli tanah sebagai berikut:

"Wong seng biasane nengkono terlibat yo jelase seng duwe tanah, pembeline, makelare karo saksi biasane saksine teko $R T$, $R W$ utowo Wong seng duwe pengaruh. Karo barange koyok tanah kuwi bisane enek sertifikate. Lek pembayarane enek seng langdung tunai tapi biasane dibayar setengah disek maringono bulan ngarep di lunasi."

Artinya: "Orang yang disitu terlibat ya jelasnya yang mempunyai tanah, pembeli, makelar dan saksi. Biasanya saksinya dari RT, RW, atau orang yang mempunyai pengaruh, sama barangnya itu biasanya ada surat atau sertifikatnya. Kalau pembayarannya ada yang langsung tunai ada yang dibayar setengah dulu baru melunasi bulan depan."

Akad jual beli tanah di Desa Karangdoro, dari hasil wawancara dengan bapak Yamdadi pelasanaan perjanjian makelar jual beli tanah yang ada di Desa Karangdoro Sebagai Berikut:

"Pelaksanaan perjanjiane le biasane mong cuman gae lisan, ora ono seng gae tulisan yo koyok contone makelar teko neng omah nawakne tanah e sakmene, yowes langsung perjanjian aq sanggup golekne wong seng ape tuku”. 
Jurnal Ekonomi Syariah Darussalam

Vol I No I Agustus 2020, ISSN: 2745-8407

Hal ini sesuai dengan yang dikatakan oleh bapak Kundari:

"Enek mas, tp gor perjanjian lesan, contone seumpamane seng duwe tanah njalok didolne tanah, pak dolno tanahku rego sakmene? trus aku ngomong "ok buk".

Sedangkan akad perjanjian jual beli tanah yang ada di Desa Karangdoro menurut bapak Katimin sebagai berikut:

"Makelare biasane moro neng omah karo seng ape tuku tanah. Baru ngelakoni transaksi. Karo enek surat perjanjian seng di gae karo deso yo karo nekakne saksi koyo pak RT, pak RW lan Kepolo Dusun karo seng duwe tanah neng sekitar tanahku ben sok mben gak enek perselisihan masalah wangket".

Artinya: "Makelar biasanya akan datang kerumah sama yang akan membeli tanah, baru melakukan transaksi, juga ada surat perjanjian yang di buat oleh desa juga mendatangkan seorang saksi seperti ketua RT, ketua RW, dan Kepala Dusun dan juga orang yang mempunyai tanah di sekitar tanahku biar nantinya tidak ada perselisihan masalah batas tanah".

Begitu juga yang dikatakan Ibu Ni'matuzzahra

"Lek tawar tawarane wes dil, maringono di temokne karo seng duwe tanah nglakoni perjanjian tertulis karo enek saksi biasane saksine yo Ketua RT utowo pak wo".

Artinya: "Kalau tawar menawarnya sudah sepakat, terus nantinya akan di temukan dengan orang yang mempunyai tanah untuk melakukan perjanjian tertulis sama ada saksi biasanya saksinya Ketua RT atau Kepala Dusun".

\section{Uji Keabsahan Data}

Pada sebuah penelitian dibutuhkan alat untuk mengecek keabsahan data atau untuk menguji keabsahan data salah satunya menggunakan triangulasi. Triangulasi merupakan teknik keabsahan data yang memanfaatkan sesuatu yang lain, di luar data itu untuk keperluan pengecekan atau sebagai pembanding terhadap data tersebut. Pada penelitian ini, uji keabsahan data menggunakan triangulasi dengan sumber.

Triangulasi dengan sumber dilakukan dengan cara membandingkan dan mengecek balik derajat kepercayaan suatu informasi yang diperoleh melalui waktu dan alat yang berbeda. Hal ini dapat dicapai dengan cara: Pertama, membandingkan data hasil pengamatan dengan hasil wawancara pada kasus jual beli tanah di Desa Karangdoro Kecamatan Tegalsari Kabupaten Banyuwangi. Kedua, membandingkan data hasil wawancara dengan teori hukum Islam. Ketiga, membandingkan data hasil wawancara penjual dengan wawancara pembeli. 
Jurnal Ekonomi Syariah Darussalam

Vol I No I Agustus 2020, ISSN: 2745-8407

Analisis Praktik Jual Beli Tanah di Desa Karangdoro Kecamatan Tegalsari Kabupaten Banyuwangi

Makelar jual beli tanah yang ada di Desa Karangdoro itu makelar yang berdiri sendiri artinya makelar bebas, dimana peran makelar adalah sebagai perantara antara penjual dan pembeli untuk mengadakan kesepakatan jual beli tanah serta mengurusi kesepakatan pembayaran yang akan dilakukan oleh penjual dan pembeli pekerjaan perantara/makelar antara orang-orang untuk transaksi komersil seperti jual beli, ijarah (sewa menyewa), dan lain-lain (Kementrian Wakaf Kuwait, 2010:151) .

Dalam mekanismenya seorang penjual atau pembeli akan mendatangi makelar dengan maksud meminta untuk menjualkan dan mencarikan tanah. Setelah menerima permintaan dari penjual tanah makelar akan menanyakan harga yang diminta oleh penjual tanah dan menanyakan kriteria tanah yang diminta oleh pembeli, setelah mengetahui harga yang diminta dan kreterianya makelar akan mencarikan tanah yang sesuai dengan permintaan pembeli atau mencari pembeli tanah dan menawarkan tanah tersebut kepada calon pembeli. Samsarah adalah pelantara perdagangan (orang yang menjualkan barang dan mencarikan barang), atau pelantara antara penjual pembeli untuk memudahkan jual beli (Sa'dudin, 2002:650).

Dalam praktik penambahan harga yang dilakukan oleh makelar biasanya makelar akan memberitahu pemilik tanah terhadap nominal yang ditambahkan oleh mereka. Semisal harga yang di tambahkan sebanyak 15 juta dari harga yang diminta oleh pemilik tanah 100 juta maka penambahan tersebut akan di beritahukan kepada pemilik tanah. Abbas berkata "Tidak apa-apa engkau mengatakan jual lah baju ini sekian, yang lebih dari itu adalah milikmu" (Qudaimah, 2005:108).

Pelaksanaan perjanjian makelara jual beli tanah yang ada di Desa Karangdoro Kecamatan Tegalsari Kabupeten Banyuwangi adalah berbentuk lesan/ucapan dari penjual kepada pembeli dan pembeli kepada makelar. Dalam mendapatkan upahnya biasanya makelar mendapatkan $5 \%$ dari hasil penjualan yang mana persenan tersebut sudah menjadi adat setempat atau mengambil dari penambahan harga jual tanah. Upah tersebut diberikan ketika tanah sudah laku terjual, dan mendapatkan 
Jurnal Ekonomi Syariah Darussalam

Vol I No I Agustus 2020, ISSN: 2745-8407

upah ketika sudah beres pekerjaan, mendapatkan izin dari pemilik barang ketika menambah harga.

Setelah makelar menemukan pembeli dan sudah melakukan tawar menawar barang dan telah terjadi kesepakatan harga dengan pembeli, maka seorang pembeli akan dipertemukan dengan pemilik tanah, yang mana pertemuan tersebut untuk melakukan sebuah perjanjian atau kesepakatan. Dalam melakukan perjanjian antara penjual dan pembeli bukan hanya menggunakan perjanjian lisan akan tetapi juga menggunakan perjanjian secara tertulis, baik berupa surat perjanjian yang di keluarkan oleh desa atau di buat oleh seorang notaris. Dalam perjanjian tersebut juga mendatangkan seorang saksi, biasanya orang yang menjadi saksi adalah tokohtokoh atau sesepuh setempat seperti Ketua RT, ketua RW dan Kepala Dusun dan juga orang yang mempunyai tanah di sekitar tanah yang akan dijual. Sighot adalah bahasa interaktif dalam sebuah transaksi, yang meliputi penawaran (ijab) dan persetujuan (qabul) (Tim Laskar Pelangi, 2013:10). Dalam transaksi jual beli, sighot di perlukan karena jual beli adalah akad yang berorentasi pada kerelaan hati (Taradlin), dan ijab qobul merupakan ekspresi paling representatif untuk pernyataan tarodlin.

\section{Analisis Tinjauan Hukum Islam Terhadap Praktek Jual Beli Tanah di Desa Karangdoro Kecamatan Tegalsari Kabupaten Banyuwangi}

Secara umum struktur jual beli terdiri dari tiga rukun, dan mendetailnya terdiri dari enam rukun, yaitu: aqidain (penjual dan pembeli), ma'qud alaih (mabi' dan tsaman), dan shighot (Ijab dan Qabul) (Tim Laskar Pelangi, 2013:4).

\section{Aqidain (Pelaku Transaksi)}

Aqidain adalah subjek atau pelaku transaksi yang meliputi penjual ( $b a^{`} i$ ) dan pembeli (mustari). Dalam praktek jual beli tanah di Desa Karangdoro orang yang menjual adalah pemilik tanah, makelar hanyalah sebagai perantara antara penjual dan pembeli. Transaksi jual beli sah jika pelaku jual transaksi (penjual dan pembeli) memiliki kreteria ahli tasaruf dan mukhtar.

a. Ahli Tasaruf adalah orang yang memiliki kreteria sah atau memiliki kompetensi dalam tasaruf tertentu. Dari hasil yang dilakukan, penjual dan pembeli dalam jual beli tanah di Desa Karangdoro sudah memenuhi kriteria ahli tasaruf yaitu balig, berakal dan tida tercegah transaksinya. 
Jurnal Ekonomi Syariah Darussalam

Vol I No I Agustus 2020, ISSN: 2745-8407

b. Mukhtar adalah orang yang melakukan transaksi atas dasar insiatif pribadi, tanpa tekanan atau paksaan dari pihak lain. Dalam jual beli tanah yang ada di Desa Karangdoro tidak ada tekanan dan paksaan baik dari penjual maupun pembeli semua karena atas inisiatif sendiri.

2. Ma'qud Alaih

Adalah komoditi dalam transaksi jual beli yang mencakup barang dagangan (mustman) dan alat pembayaran (tsaman). Syarat ma'qud alaih dalam jual beli adalah: suci, mutaqowwim atau mutamawwal, muntafa' bih, maqdur ala taslim, li al aqid wilayah, dan ma'lum (Team Kajian Ilmiah Ahla Suffah, 2013:265).

a. Suci atau mungkin di sucikan dengan dibasuh seperti benda mutanajis (terkena najis). Barang yang di perjual belikan adalah tanah, yang mana sudah memenuhi kreteria suci.

b. Mutaqowwim atau Mutamawwal yaitu bisa memiliki nilai jual dan manfaat ketika barang mengalami lonjakan harga. Barang yan diperjual belikan adalah tanah yang mana memiliki nilai jual dan nilai manfaat ketika mengalami lonjakan.

c. Muntafa' bih memiliki nilai manfaat menurut standar syara' dan urf meskipun bersifat potensial, objek dalam jual beli adalah tanah yang mana sudah memenuhi kriteria muntafa' bih yaitu memiliki nilai manfaat.

d. Maqdur Ala Taslim bisa di terima oleh pihak pembeli baik secara hissy maupun syar' $i$. Jual beli tanah yang ada di Desa Karangdoro dalam penyerah terimaan tanah melakukan perjanjian tertulis, sehingga sudah memenuhi syarat maqdur ala taslim.

e. Li al Aqid Wilayah yaitu memiliki hak kuasa terhadap ma'qud alaih baik dengan kepemilikan penuh, menurut hasil observasi yang peneliti lakukan, dalam jual beli tanah yang dilakukan di Desa Karangdoro, tanah yang di perjual belikan adalah benar- benar milik dari seseorang yang menjual tanah.

f. Ma'lum yaitu penjual dan pembeli mengetahui ma'qud alaih baik dari segi 'ain (bentuk barang), ukuran dan sifatnya. Dalam jual beli tanah yang dilakukan di Desa Karangdoro, tanah dan harga yang di perjual belikan, baik penjual dan pembeli sudah mengetahui. 
Jurnal Ekonomi Syariah Darussalam

Vol I No I Agustus 2020, ISSN: 2745-8407

3. Sighot

Sighot adalah bahasa interaktif dalam sebuah transaksi, yang meliputi penawaran (ijab) dan persetujuan (qabul). Dalam transaksi jual beli, sighot di perlukan karena jual beli adalah akad yang berorentasi pada kerelaan hati (taradlin), dan ijab qobul merupakan ekspresi paling representatif untuk pernyataan tarodlin. (Tim Laskar Pelangi, 2013:10).

Dalam pelaksanaan perjanjian jual beli tanah yang dilakukan masyarakat Desa Karangdoro Kecamatan Tegalsari Kabupaten Banyuwangi dengan cara perjanjian tertulis. Pada waktu melakukan ijab dan qabul pada akad jual beli, masyarakat Desa Karangdoro menggunakan bahasa daerah (yaitu bahasa jawa) sebagaimana kebisaaan sehari-hari masyarakat tersebut agar kedua belah pihak dapat dengan mudah memahami maksud dan tujuan yang dituju atau dikomunikasikan.

Dari analisis di atas menunjukan bahwa praktek jual beli tanah di Desa Karangdoro Kecamatan Tegalsari Kabupaten Banyuwangi menurut hukum Islam diperbolehkan karena sudah memenuhi syarat dan rukun jual beli.

Sedangkan praktek penambahan harga yang dilakukan oleh makelar dalam jual beli tanah di Desa Karangdoro Kecamatan Tegalsari Kabupaten Banyuwangi biasanya makelar akan memberitahu pemilik tanah terhadap nominal yang di tambahkan oleh mereka. Semisal harga yang di tambahkan sebanyak 15 juta dari harga yang diminta oleh pemilik tanah 100 juta maka penambahan tersebut akan di beritahukan kepada pemilik tanah. Dari pemaparan di atas praktek penambahan harga yang dilakukan oleh makelar di perbolehkan dalam Hukum Islam karena sesuai teori:

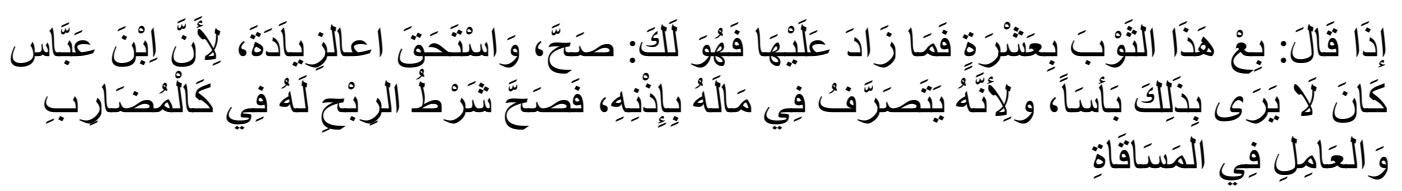

Artinya: "Ketika pemilik barang mengatakan, jualkan kain ini dari saya 10 dirham, jika laku lebih, itu milik kamu, maka akadnya sah, dan makelar berhak mendapatkan tambahan itu. Karena menurut Ibnu Abbas itu dibolehkan, dan makelar melakukan transaksi terhadap barang orang ini, atas izinnya. Sehingga sah adanya kesepakatan pembagian keuntungan menjadi miliknya, seperti mudharib dan amil dalam akad musaqah" (alMughni, 5/108).

Dari analisis yang dilakukan peneliti menyimpulkan bahwa praktek jual beli yang dilakukan di Desa Karangdoro Kecamatan Tegalsari Kabupaten Banyuwangi 
Jurnal Ekonomi Syariah Darussalam

Vol I No I Agustus 2020, ISSN: 2745-8407

sudah sah menurut hukum Islam karena sudah memenuhi syarat dan rukun jual beli, dan penambahan harga yang dilakukan oleh makelar di perbolehkan dalam hukum Islam karena sudah disebutkan di awal dan atas sepengetahuan dari pemilik tanah.

\section{E. KESIMPULAN}

1. Praktek jual beli tanah di Desa Karangdoro Kecamatan Tegalsari Kabupaten Banyuwangi ada dua cara yaitu, dengan melalui makelar dan di jual sendiri/tanpa makelar. Dalam jual beli melalui makelar, seorang penjual atau pembeli akan mendatangi makelar dengan maksud meminta untuk menjualkan dan mencarikan tanah dan juga menyebutkan harga yang diminta. Setelah mengetahui harga yang diminta oleh pemilik tanah, makelar akan mencari pembeli dan menawarkan barangnya. Ketika ada tambahan harga jual beli tanah biasanya makelar akan memberitahukan kepada pemilik tanah. Setelah makelar melakukan kesepakatan harga dengan pembeli, maka pembeli akan di pertemukan dengan pemilik tanah untuk melakukan sebuah perjanjian atau kesepakatan yang mana dalam perjanjian tersebut menggunakan perjanjian secara tertulis, baik berupa surat perjanjian yang di keluarkan oleh desa atau di buat oleh seorang notaris, dan juga mendatangkan saksi baik dari tokoh-tokoh atau sesepuh setempat seperti ketua RT, ketua RW dan Kepala Dusun dan juga orang yang mempunyai tanah di sekitar tanah yang akan dijual.

2. Tinjauan Hukum Islam terhadap praktek jual beli tanah di Desa Karangdoro Kecamatan Tegalsari Kabupaten Banyuwangi peneliti menyimpulkan bahwa praktek jual beli tanah yang dilakukan sah karena sudah sesuai dengan syarat dan rukun jual beli dan penambahan harga yang dilakukan oleh makelar sah secara Hukum Islam karena atas sepengetahuan pemilik tanah.

\section{Implikasi Penelitian}

Dari hasil penelitian ini dimaksudkan jika praktik jual beli tanah yang dilakukan masyarakat Desa Karangdoro tidak sesuai dalam hal penambahan harga dengan hukum Islam maka diharapkan dengan adanya penelitian ini masyarakat dalam melakukan penambahan harga sesuai dengan Hukum Islam.

\section{Keterbatasan Penelitian}

Penelitian yang dilakukan oleh penulis ini memiliki keterbatasan yaitu waktu yang dilakukan dalam pelaksanaan penelitian ini terbilang relatif singkat, maka 
Jurnal Ekonomi Syariah Darussalam

Vol I No I Agustus 2020, ISSN: 2745-8407

dalam melakukan penelitian ini kurang maksimal, diharapkan dalam melakukan penelitian selanjutnya dalam waktunya lebih panjang agar hasilnya dapat maksimal.

\section{Saran}

Berdasarkan pembahasan dan kesimpulan di atas, ada beberapa hal yang di sampaikan peneliti, yaitu sebagai berikut:

1. Kepada makelar dalam melakukan jual beli khususnya dalam penambahan harga harus sesuai dengan ketentuan hukum Islam.

2. Kepada akademis, hasil penelitian ini dapat dijadikan bahan referensi bagi peneliti yang akan datang, maka dari itu diharapkan bagi pihak kampus agar dapat menyediakan referensi berupa artikel, jurnal atau buku-buku yang berhubungan dengan jual beli terutama yang Islami. Agar peneliti yang akan datang tidak lagi kebingungan dalam mencari referensi. Sehingga nantinya dapat mempermudah peneliti yang akan datang dalam menyelesaikan penelitiannya.

3. Kepada peneliti selanjutnya diharapkan dapat mencari data yang lebih banyak lagi, agar hasil yang diperoleh di akhir dapat lebih baik lagi. Berhubungan dengan teori yang digunakan dalam peneliti yang akan datang diharapkan agar materinya diperbanyak lagi, karena teori yang dipakai dalam penelitian ini dirasa masih belum sepenuhnya mendukung hasil penelitian.

\section{DAFTAR PUSTAKA}

Abdullah, Huedi dan Beni Ahmad Saebani. 2014. Metede Penelitian Ekonomi Islam. Bandung: Pustaka Setia.

Afandy, Sulaiman. 2016. Tinjauan Hukum Islam terhadap Jual Beli Tanah Pemakaman Modern di Karawang. Skripsi. Yogyakarta: Universitas Islam Negeri Sunan Kalijaga.

Basyir, Ahmad Azhar. 2000. Asas-asas Hukum Muamalat. Yogyakarta: UII Press

Emzir. 2014. Metodologi Penelitian Kualitatif: Analisis Data. Jakarta: Rajawali Press.

Farida Khiftyani, Ida. 2016. Tinjauan Hukum Islam Terhadap Jual Beli Tanah Sawahan di Desa Ngabar kecamatan Siman Kabupaten Ponorogo. Skripsi. Ponorogo: IAIN Ponorogo.

Hibatullah. 2016. Tinjauan Hukum Islam Terhadap Praktik Jual Beli Kain Batik di Mlangi Nogotirto Gamping Sleman. Skripsi. Yogyakarta: Universitas Islam Negeri Sunan Kalijaga.

Moleong, Lexy J. 2014. Metode Penelitian Kualitatif. Bandung: PT Remaja Rosdakarya.

Muhammad bin Qosim Al-Ghozi. 1343. Fathul Qorib. 
Jurnal Ekonomi Syariah Darussalam

Vol I No I Agustus 2020, ISSN: 2745-8407

Subagiyo, Rokhmat. 2017. Metode Penelitian Ekonomi Islam: Konsep dan Penerapan. Jakarta: Alim's Publishing.

Tim Kajian Ilmiah FKI Ahlu Shuffah. 2013. Kamus Fiqh. Kediri: Lirboyo Press.

Tim Laskar Pelangi. 2013. Metodologi Fiqh Muamalah. Kediri: Lirboyo Press.

Kementrian, Wakaf dan Urusan Agama Kuwait. 1883. Al-Maushu'ah AlFiqhiyyah.

Zuhaili, Wahbah Penerjemah Abdul Hayyie Al-Kattani. 2007. Fiqih Islam Wa Adilatuhu, Jilid V. Jakarta: Gema Insani.

Profil Desa Karangdoro Kecamatan Tegalsari Kabupaten Banyuwangi Tahun 2018. 